\title{
Why Do Churches Become Empty, While New Age Grows? Secularization and Religious Change in the Netherlands
}

\author{
DICK HOUTMAN \\ PETER MASCINI
}

\begin{abstract}
Research from the Netherlands has pointed out that the increased popularity of New Age since the 1960s by no means compensates for the dramatic decline of the Christian churches. From a theoretical point of view, however, it is more important to study why those remarkably divergent developments have occurred in the first place. This article does this by analyzing survey data collected among the Dutch population at large in 1998, focusing on a comparison of the young and the elderly. It is concluded, first, that there are no indications that the decline of the Christian tradition has been caused by a process of rationalization. Second, the decline of the Christian tradition and the growth of nonreligiosity as well as New Age are caused by increased levels of moral individualism (individualization). Implications for the sociological analysis of cultural and religious change are discussed.
\end{abstract}

If we have to make one element of modernization central to understanding the nature of modern religion, it would be that which explains the rise of the sect, the tolerance at the heart of the denomination, and the amorphous nature of the cult: individualism. (Bruce 1995:428)

\section{INTRODUCTION}

The Dutch religious landscape has changed dramatically since the 1960s. The percentage of people who are not affiliated with one of the Christian churches has increased from 24 percent in 1958 to about 60 percent today. As a result, in 1999, only 18 percent of the Dutch population considered itself Roman Catholic, only 15 percent felt affiliated with either of the two principal Protestant churches in the Netherlands ( 8 percent-Dutch Reformed, 7 percent-Neo-Calvinists), while the residual category "other churches" accounts for an even lower percentage (Becker and De Wit 2000:13; see also Becker, De Hart, and Mens 1997:57-61; Becker and Vink 1994). It is difficult to find other countries where the Christian tradition has eroded so rapidly and dramatically during the last few decades.

According to some, this means that Dutch culture and society have become increasingly secular since the 1960s (e.g., Becker and Vink 1994). Others, however, emphasize that the decline of the Christian tradition has been accompanied by the rise of a veritable "experimental garden of religiosity" (Janssen 1998). Now that "new," "alternative," or "posttraditional" types of religion, among which New Age figures prominently, are flowering alongside the remains of the Christian tradition, they argue, New Age can no longer be considered a marginal phenomenon at the fringe of contemporary culture (Moerland and Van Otterloo 1996; Aupers 2000; Van Otterloo 1999). Although to the best of our knowledge time-series data on the acceptance of typical New Age beliefs among the Dutch population are not available, evidence for the growth of New Age in the Netherlands is not completely absent. The authors we have just referred to, for instance, point at the substantial growth since the 1960s of the number of New Age centers, the sales records of

Dick Houtman is an Assistant Professor of Sociology, Department of Sociology, Faculty of Social Sciences, Erasmus University, P.O. Box 1738, 3000 DR Rotterdam, the Netherlands. Email: Houtman@fsw.eur.nl

Peter Mascini is a postdoc of sociology in the Department of Sociology, Faculty of Social Sciences, Erasmus University, P.O.Box 1738, 3000 DR Rotterdam, the Netherlands.Email: Mascini@fsw.eur.nl 
New Age books, and the circulation of New Age magazines.

Given the remarkably divergent developments of the Christian tradition and New Age, the Netherlands constitutes a strategic case study in the debate on secularization and emerging new types of religiosity. More specifically, this dual development poses a fascinating problem of sociological explanation: How can the simultaneous erosion of the former and growth of the latter type of religion be explained? This problem of explanation is often neglected in the literature, as many studies of secularization and religious change are descriptive in orientation and document the rise or decline of particular types of religion (e.g., Voyé 1999; Lambert 1999; Roof 2000; Roof, Carroll, and Roozen 1995). This descriptive orientation is shared by Becker, De Hart, and Mens (1997) and Wallis and Bruce (1984), who have demonstrated that the exodus from the Christian churches outnumbers the growth of new types of religion and conclude that the net trend is one of secularization.

As to explanations, Stark and Bainbridge's (1985) "supply-side" theory of religious change has, of course, been enormously influential by stimulating empirical research and critical theoretical debate (e.g., Wallis 1986; Nock 1989; Robertson 1992; Miller 1995; Bader and DeMaris 1996). Two other influential theories, however, have in fact hardly been tested systematically, although they seem to be accepted as valid by many sociologists. Therefore, in the present article, we focus on those theories, both of which consider secularization and religious change as closely related to processes of modernization. The first, the thesis of rationalization, predicts religious decline as a consequence of a process of rationalization. The second, the thesis of individualization, predicts religious change as a consequence of a process of individualization. Not surprisingly, then, those theories propose quite different answers to the question addressed in this article: Why do the churches become empty, while New Age grows?

We start our article with a theoretical elaboration of those two theories to specify the explanations of the downfall of the Christian churches and simultaneous growth of New Age. Given the unfortunate absence of relevant longitudinal or time-series data, we next explain how the resulting hypotheses can be tested by means of common survey data, focusing on a comparison of the young and the elderly. After a discussion of those survey data and the measurement of our theoretical concepts, we introduce LISREL as the most appropriate method to test our hypotheses. After the presentation of our findings, we conclude with a brief summary of our results and a discussion of their implications for the study of secularization and religious change.

\section{Secularization and Religious Change: The Theses of Rationalization AND INDIVIDUALIZATION}

\section{The Thesis of Rationalization}

About one and a half centuries ago, Auguste Comte argued that a "theological" worldview, which holds supernatural forces responsible for the origin and nature of things, has historically been substituted first by a "metaphysical" and at last by a "positive" worldview. According to him, magic-mystical and religious interpretations of reality have been more and more repelled by scientific knowledge, while magic as a means to control the environment ("applied religion") has increasingly been dispelled by technology ("applied science") (1974 [1851-1854]). Comte's theory does not stand by itself, but is a typical part of an extensive intellectual tradition, which also includes thinkers such as Spencer, Marx, Tylor, Freud, and Levy-Bruhl:

traditional claims concerning the incompatibility of science and religion and predictions of science's contribution to religion's inevitable demise have always been framed in terms of physical science discoveries that expose the fallacies of religious superstitions and technological progress that reduces the appeal of religious promises. (Iannaccone, Stark, and Finke 1998:384) 
This idea that the growth of scientific knowledge pushes religion to the margins of modern consciousness is still alive today. American anthropologist Wallace, for example, claims that "belief in supernatural powers is doomed to die out, all over the world, as a result of the increasing adequacy and diffusion of scientific knowledge ... the process is inevitable" (cited by Stark and Finke 2000:29). Although today the alleged incompatibility of science and technology with religion is typically discussed at the macro or societal level (e.g., Wilson 1976, 1982; Dobbelaere 1999; Lechner 1991), this still assumes a similar relationship at the level of individual consciousness (see, for a further discussion of this point, Stark 1999). Dobbelaere, for instance, writes:

\footnotetext{
many people [can] no longer believe in God because not only the material and the physiological world seem controllable, but the social and psychical world as well. People think more and more that they can control and manipulate "their" world. They act more in terms of insight, knowledge, controllability, planning and technique and less in terms of faith. (1993:15, our translation from Dutch, DH/PM)
}

In this article we refer to this theoretical logic as the "thesis of rationalization": the idea that the space left over for religion decreases with the rise of the conviction that true and objective scientific knowledge exists, which can be utilized to control the environment. This thesis of rationalization should not be confused with Max Weber's ideas about the disenchantment of the world, which refer to the gradual decline of the appearance of the world as a "magic garden," dominated by mysterious and unpredictable powers, controllable by magical means only. According to Weber, this magic garden gives way not only to the idea of an inanimate nature, controllable by means of technology, based on scientific knowledge, but also to the skeptical idea that no such thing as an "objective" meaning exists. So, with the disenchantment of the world, the idea that meaning is inevitably a human creation, lacking any meta-social or supernatural foundation, becomes increasingly widespread. As a consequence, Weber's ideas on the disenchantment of the world, as distinct from the thesis of rationalization mentioned above, leave open the possibility that rationalism itself will become critically scrutinized and found wanting (although Weber has never elaborated this problem himself). Cultural changes since the 1960s point out that precisely this has happened.

As part of a process of "reflexive modernization" (Beck 1992; Beck, Giddens, and Lash 1994) or "postmodernization" (Crook, Pakulski, and Waters 1992; Inglehart 1997), the past few decades have not only witnessed an erosion of the Christian tradition, but a declining faith in science and technology as well. Moreover, the latter development is not restricted to the general public. It has also taken place in the field of knowledge and the universities. Especially among intellectual circles in the arts, philosophy, and anthropology, the postmodern conviction that "knowledge" is ultimately "man made" rather than "found" has gained quite a lot of influence (e.g., Gross and Levitt 1994). This conviction entails a radicalized skepticism, which can be understood as the product of the disenchantment of the world. After all, postmodernism considers not only religious and cultural ideas, but even "scientific truths" as products of the human mind awaiting their eventual deconstruction. It goes without saying that precisely this postmodern denial of the distinction between religious and cultural ideas on the one hand, and scientific knowledge on the other, makes postmodernism hard to swallow for most scientists.

In short, developments since the 1960s point out, first, that rationalism is not the inevitable and undisputed "end of history" that the thesis of rationalization holds it to be. It has in fact gradually become an important focus of cultural conflict within the field of knowledge and the universities. Second, developments since the 1960s suggest that the cultural dynamics of modern Western societies do not simply spring from a "religion/science conflict" (Sappington 1991) or a "warfare of science with theology" (White 1960). After all, since the 1960s both the Christian tradition and science and technology seem to have lost part of their former appeal. As rationalism has not become more widespread, but has increasingly been challenged, it is unlikely that the 
gradual erosion of the Christian tradition is a consequence of a process of rationalization, as the thesis of rationalization holds.

But, of course, we cannot jump to conclusions just like that. It might be argued, for instance, that contemporary theories of reflexive modernization and postmodernization have hardly been tested systematically. The alleged decline of rationalism addressed by those theories might thus actually reflect a changing mood among Western intellectuals rather than a similar change among the mass publics of Western societies (see, however, Inglehart 1997). As a consequence, it is quite important to study empirically whether, notwithstanding fashionable ideas about reflexive modernization and postmodernization, the downfall of the Christian tradition since the 1960s can nevertheless be explained by an increased faith in science and technology among the mass public during this same period. If the thesis of rationalization is tenable, we should be able to demonstrate that older generations are more often Christian, while younger generations are more often nonreligious, because the former are less rationalistic than the latter. ${ }^{1}$ As discussed above, as understood within the context of the thesis of rationalization, "rationalism" refers to the conviction that true and objective scientific knowledge exists, which can be applied in the form of technology to control the environment.

Because the thesis of rationalization assumes a necessary tension between faith in scientific knowledge and technology on the one hand and all sorts of religion on the other, it is extremely difficult to reconcile it with the growing popularity of New Age. The idea of rationalization as the principal driving force toward a nonreligious future can thus be salvaged only by arguing that New Age and other posttraditional types of religion are either not real religions or perfectly socially unimportant types of religion (e.g., Wilson 1976; Dobbelaere 1999). Like Stark and Bainbridge (1985:436-37) we are quite skeptical about such theoretical attempts to safeguard the thesis of rationalization from falsification by exorcising the ghost of posttraditional religion from the domain of "real" or "important" religion. For now, it suffices to conclude that the growth of New Age as a contemporary type of religion is inconsistent with the thesis of rationalization. Although it yields a clear hypothesis concerning the cause of the erosion of the Christian churches during the past few decades, the theory cannot satisfactorily account for the simultaneous growth of New Age.

\section{The Thesis of Individualization}

Obviously, the idea of an eventual disappearance of religion, as predicted by the thesis of rationalization, is not universally accepted among sociologists of religion. Those who reject this idea do not, of course, deny that the Christian tradition has lost some of its cogency, but they emphasize that religion has radically changed character. In its most influential formulation, Luckmann (1967), 35 years ago, argued that as individual consciousness becomes detached from specific social contexts, people develop a sense of individual autonomy. As a consequence, Luckmann argues, traditional Christianity makes way for more or less "invisible" and "privatized" forms of religion, which are characterized by an emphasis on self-expression, self-actualization, and individual freedom. Today, Luckmann (1996) considers New Age, in which individual spiritual development is a dominant theme, but stable organization, canonized dogmas, a system of member-recruitment, and a disciplinary system are conspicuously absent, as the most prominent contemporary representative of this type of religion.

Heelas (1996) offers a similar explanation of the rising popularity of New Age. As he sees it, New Agers, in constructing their identity and arriving at moral judgments, characteristically reject guidance by any kind of "external" tradition or authority. Instead, they consider their "self" the principal moral authority:

Much of the New Age would appear to be quite radically detraditionalized (rejecting voices of authority associated with established orders) or in other ways anti-authoritarian (rejecting voices of those exercising authority on their 
own, even rejecting "beliefs".... The basic idea ... is that what lies within—experienced by way of "intuition", "alignment" or an "inner voice"- serves to inform the judgements, decisions and choices required for everyday life. The "individual" serves as his or her own source of guidance. (Heelas 1996:22-3, italics in original).

In this way, like Luckmann, Heelas (1996) relates the rising popularity of New Age to decreasing acceptance of traditions and authorities and increasing moral individualism:

\footnotetext{
The ... rejection of external voices of authority, together with the importance attached to Self-responsibility, expressivity, and, above all, authority, goes together with the fact that one of the absolutely cardinal New Age values is freedom. Liberation from the past, the traditional, and those internalized traditions, egos; and freedom to live a life expressing all that it is to be truly human. (1996:26; compare Heelas, Lash, and Morris (1995) on "detraditionalization")
}

In this article, we refer to this idea of Luckmann and Heelas as the "thesis of individualization," which argues that the rising popularity of New Age results from an increase of moral individualism. The available empirical evidence confirms two key assumptions made by Luckmann and Heelas. First, moral individualism has, indeed, become increasingly widespread during the past few decades (e.g., Inglehart 1977, 1990, 1997). ${ }^{2}$ Second, the relationship between moral individualism and the Christian tradition is indeed strained: typically, negative correlations between Christianity and moral individualism are reported. The reader is referred, for example, to Middendorp (1991) and Vollebergh, Iedema, and Raaijmakers (1999) for the Netherlands and to Olson and Carroll (1992) and Woodrum (1988a, 1988b) for the United States. Although we encounter this moral individualism in the research literature under different headings, ${ }^{3}$ all of those refer to essentially the same sort of moral individualism: the granting of a moral primacy to individual liberty.

\section{Individualization, Secularization, and Religious Change}

Nonetheless, as it is formulated by Luckmann and Heelas, the thesis of individualization is not completely free of problems. As they see it, religious change rather than secularization is taking place: as moral individualism spreads, Christianity makes way for posttraditional types of religion such as New Age. However, research points out that, certainly in the Netherlands, the downfall of the Christian tradition strongly outnumbers the growth of New Age and other new religious movements (Becker, De Hart, and Mens 1997). So, although Luckmann and Heelas seem right in arguing that a growing moral individualism has undermined the Christian tradition, they seem to neglect the circumstance that, besides New Age, nonreligiosity is an important option as well. In short, whereas the thesis of rationalization tends to neglect the rise and growth of posttraditional forms of religiosity (religious change), the thesis of individualization neglects the possibility of a genuine decline of religion (secularization).

Following Luckmann and Heelas, to the extent the process of substitution of New Age for Christianity has been taking place, we should be able to confirm the hypothesis that the young have more affinity with New Age, while the old are more often Christian, because the young are more individualistic than the elderly. A second variant of the thesis of individualization needs to be added to this first one, however, to allow for the possibility of a process of genuine secularization. ${ }^{4}$ Unlike the version proposed by Luckmann and Heelas, this second variant of the thesis of individualization does not predict substitution of Christianity by New Age (religious change), but substitution of Christianity by nonreligiosity (secularization). To the extent this second variant of the thesis of individualization is tenable, we should be able to confirm the hypothesis that the young are more often nonreligious, while the old are more often Christian, because the young are more individualistic. 


\section{HYPOTHESES}

\section{Testing Hypotheses by Means of One-Shot Survey Data}

As we have already indicated, the hypotheses derived from the theses of rationalization and individualization should, ideally, be tested by means of longitudinal or time-series data, but those data simply do not exist. Therefore, in the current article, we analyze common "oneshot" survey data, focusing on a comparison of the young and the elderly. As this is obviously a second-best option that poses some nasty methodological problems, this approach requires some explanation and justification. The key problem, of course, is whether differences between the young and the elderly with respect to rationalism, individualism, Christianity, and New Age can be interpreted as indicating processes of historical change. Obviously, the alternative possibility, that such differences reflect changes that have taken place during the lifecycle, cannot be dismissed out of hand.

Although the problem cannot be solved completely, available empirical evidence and common sense suggest that the age effects we are dealing with primarily reflect differences between age cohorts and, consequently, processes of historical change. As it happens, research by Inglehart (1977, 1990, 1997), among others, points out that the moral individualism of the young does not change into "cultural conservatism," "authoritarianism," "conformism," or "traditionalism" as they grow older (see also Meloen and Middendorp 1991). So, the individualism of the young cannot be understood as a consequence of the stage of life they are in, but results primarily from a historical process of individualization. Likewise, Te Grotenhuis (1999) has demonstrated convincingly that the substantially higher frequency of Christianity among the elderly as compared with the young indicates a historical process of change as well. Although we know of no research that demonstrates the same for the affinity with New Age among the young as compared with the old, it does not seem very plausible to assume that today's older Christians were New Agers during their youth.

Whereas it is thus not too problematical to interpret differences between the old and the young with respect to individualism, Christianity, and New Age as indicating processes of historical change, this is less so for rationalism. However, if authors like Beck and Inglehart are right, a stronger rationalism among the young is not even to be expected: if rationalism has declined during the past few decades, a stronger rationalism among the old should be found. The awkward question whether or not high levels of rationalism among the young, assumed by the thesis of rationalization, indicate a historical process of change will thus probably not even rise. We have therefore decided not to solve this methodological problem by measuring rationalism indirectly through a high level of education, as others have done (e.g., Gadourek 1998:104-40). ${ }^{5}$ A second reason to reject this strategy is that it boils down to solving a methodological problem by creating a theoretical one. As it happens, a high level of education seems a more valid (albeit crude) indicator for individualism than for rationalism. ${ }^{6}$ Besides, even if level of education would indicate both rationalism and individualism, this would mean that those two phenomena are confounded rather than disentangled. Therefore, in the current article, we measure individualism and rationalism directly and accept the methodological problem in the case of rationalism as the price to be paid for this.

\section{Hypotheses}

Our theoretical discussion has yielded three hypotheses, which can be tested by means of an analysis of common "one-shot" survey data (see Figure 1). The first hypothesis is derived from the thesis of rationalization to explain the exodus from the Christian churches. If a process of rationalization has eroded Christianity and has thus led to a rise of nonreligiosity (secularization), we should find that older generations are more often Christian, while younger 
FIGURE 1

THREE HYPOTHESES: SECULARIZATION AS PREDICTED BY THE THESIS OF RATIONALIZATION (1), SECULARIZATION AS PREDICTED BY THE THESIS OF INDIVIDUALIZATION (2), AND RELIGIOUS CHANGE AS PREDICTED BY THE THESIS OF INDIVIDUALIZATION (3)

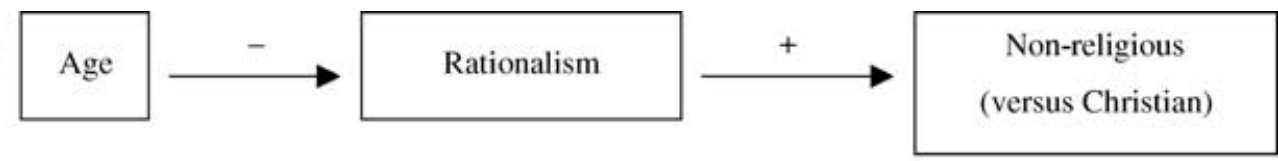

(2)

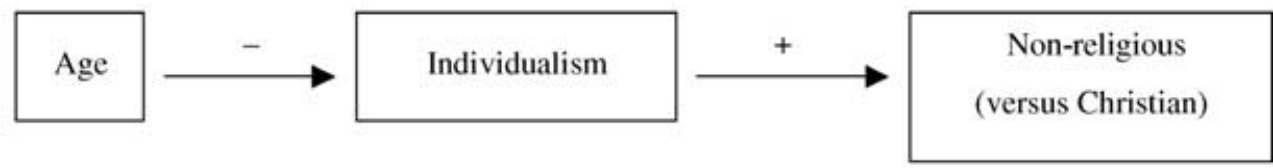

(3)

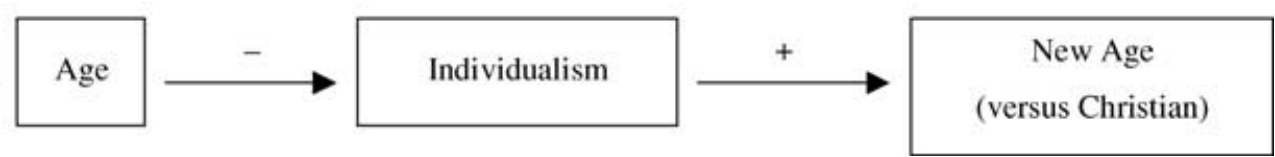

generations are more often nonreligious, because the former are less rationalistic than the latter (Hypothesis 1).

Because the thesis of rationalization cannot satisfactorily explain the rise of New Age as a posttraditional type of religion, the two remaining hypotheses are derived from the thesis of individualization. If a process of individualization is responsible for an erosion of the Christian tradition and has thus caused a growth of both nonreligiosity (secularization) and New Age (religious change), two hypotheses about the relationships between age, individualism, and type of religiosity should be supported by the empirical evidence. First, if the process of individualization has led to secularization, the young should be nonreligious more often and the old Christian more often, because the young are more individualistic than the old (Hypothesis 2). Second, if the process of individualization has led to religious change, the young should have more affinity with New Age and the old should be Christian more often, because the young hold more individualistic views than the old (Hypothesis 3).

\section{Data, Measurement, and Method}

Data

The data to be analyzed constitute the first prize in the 1997 contest Wie ontwerpt het beste Telepanel-onderzoek? (Who Designs the Best Telepanel Study?) of CENTERdata (Catholic University of Brabant (KUB)), which the first author won in cooperation with Manu Busschots and Sjaak Braster. CENTERdata's assignment is the maintenance of a Dutch nationally representative panel of respondents of 16 years or more. All panel members have been given a home computer to provide Dutch social scientists with access to such a sample. The data for the current project were collected in the summer of 1998. The response rate was 75 percent, yielding a sample of 1,848 respondents. The sample is representative of the Dutch population aged 16 years or more with respect to age and level of education, but women are somewhat underrepresented. Because we do not know whether the beliefs and attitudes of the women in our sample differ from those of the nonrespondents, we have decided not to correct for this by means of a weighting procedure. 
After all, such a procedure might worsen rather than solve the problem. Moreover, none of our hypotheses relates to gender.

\section{Measurement}

Religiosity is not reduced to a dichotomy such as "religious" versus "nonreligious" or "Christian" versus "non-Christian." We use a trichotomy instead: "Christian," "New Age," and "nonreligious." Three types of indicators for religiosity (religious or not religious) and the nature of religiosity (Christian and/or New Age) are combined to construct it.

New Age is notoriously difficult to operationalize. To enable a comparison with earlier Dutch studies by De Hart (1993), Becker, De Hart, and Mens (1997), and Bernts and Van der Hoeven (1998), we have followed those by presenting our respondents with some practices closely related to New Age - reincarnation, astrology, New Age, yoga, and oriental religions-asking them to what extent they have been involved in each. As this operationalization only indirectly captures the presence of ideas characteristic of New Age, we have added five Likert-type items (agree strongly through disagree strongly), taken from Gussenhoven and Van den Maagdenberg (1998) in a slightly modified form. Those items express four core ideas of New Age (e.g., Hanegraaff 1996; Heelas 1996). The first is holism: the conviction that all elements discernible within man, world, and universe essentially constitute a unity and continuously influence one another. The following statements refer to this conviction: "One's character is strongly determined by the stars and planets" and "One can predict one's future to a large extent by reading the lines in one's hand." The second core idea is the occurrence of a process of spiritual transformation, which has been operationalized through an item expressing a belief in reincarnation: "After death, one's soul passes to another human being or animal." The third core idea of New Age is syncretism, the conviction that the attainment of personally meaningful spirituality requires an individual combination of religious ideas and practices. This conviction has been operationalized through the item "One should search in different religions oneself to make one's own religion." Fourth and finally, we included an item tapping perennialism - the conviction that all religious traditions and ideas refer, essentially, to the same esoteric truth: "The one and only true religion does not exist, but there are truths one can find in all religions of the world." Those involved in the five practices proved to agree most strongly with those five items as well. ${ }^{7}$ This suggests that both series of five questions measure roughly the same, as we intended and expected. The combination of those 10 questions produces a single reliable scale (Cronbach's $\alpha=0.78$ ), which we consider a valid measure of affinity with New Age.

The type of transcendental consciousness is determined with the question of which of the following statements best reflects one's personal conviction: (1) "There is a God who personally occupies himself with every human being" (27 percent); (2) "There has to be something like a higher force that controls life" (33 percent); (3) "I don't know whether there is a God or a higher force" (27 percent); (4) "There is no God or higher force" (12 percent). The idea was that Christians would choose the first option, New Agers the second, and nonreligious persons the third and especially the fourth.

Church membership was ascertained simply by asking whether (51 percent) or not ( 49 percent) one considers oneself as belonging to a church.

After having divided the scale for affinity with New Age into five categories, about equal in size, the three indicators for (type of) religiosity mentioned above have been analyzed with HOMALS (SPSS). The HOMALS analysis produces a well-interpretable two-dimensional solution, with a first dimension indicating affinity with the Christian tradition and a second indicating affinity with New Age (see Table 1). For the respondents with a missing value on either the New Age scale (120 respondents; 6 percent) or the church membership variable (only four respondents) the quantifications on those two dimensions are estimated by HOMALS. This is a standard 
TABLE 1

RESULTS OF HOMALS ANALYSIS OF INDICATORS FOR (TYPE OF) RELIGIOSITY

\begin{tabular}{|c|c|c|c|c|c|}
\hline & \multirow[b]{2}{*}{ Frequency } & \multicolumn{2}{|c|}{ Dimension 1} & \multicolumn{2}{|c|}{ Dimension 2} \\
\hline & & $\begin{array}{c}\text { Category } \\
\text { Quantification }\end{array}$ & $\begin{array}{l}\text { Discrimination } \\
\text { Value }\end{array}$ & $\begin{array}{c}\text { Category } \\
\text { Quantification }\end{array}$ & $\begin{array}{c}\text { Discrimination } \\
\text { Value }\end{array}$ \\
\hline Church membership & & & 0.81 & & 0.01 \\
\hline 1. No & 904 & -0.92 & & 0.07 & \\
\hline 2. Yes & 940 & 0.88 & & -0.06 & \\
\hline Missing & 4 & & & & \\
\hline $\begin{array}{l}\text { Type of transcendental } \\
\text { consciousness }\end{array}$ & & & 0.81 & & 0.70 \\
\hline 1. God & 508 & 1.12 & & -0.79 & \\
\hline 2. Force & 604 & 0.25 & & 0.92 & \\
\hline 3. Doubt & 506 & -0.79 & & 0.32 & \\
\hline 4. No belief & 230 & -1.49 & & $\begin{array}{c}-1.35 \\
0\end{array}$ & \\
\hline Affinity with New Age & & & 0.02 & & 0.62 \\
\hline 1. None & 348 & -0.11 & & -1.48 & \\
\hline 2. Very weak & 343 & -0.14 & & -0.08 & \\
\hline 3. Weak & 346 & 0.21 & & 0.28 & \\
\hline $\begin{array}{l}\text { 4. Neither weak, } \\
\text { nor strong }\end{array}$ & 346 & 0.14 & & 0.28 & \\
\hline 5. Strong & 345 & -0.03 & & 0.97 & \\
\hline Missing & 120 & & & & \\
\hline Eigenvalue & & & 0.55 & & 0.44 \\
\hline
\end{tabular}

$\mathrm{N}=1,848$.

procedure that makes use of two sorts of available information: (1) the scores of those respondents on the two variables for which scores are available and (2) the estimated relationships between the (categories of the) three variables for the respondents without any missing values. On the basis of the HOMALS solution, the 1,848 respondents can be classified into four religious types: nonreligious (35 percent), Christian (44 percent), New Age (14 percent), and a mixed Christian/New Age type ( 7 percent). The relatively small last mentioned category (126 respondents; 7 percent) is excluded from the subsequent statistical analysis, as our hypotheses relate to the first three religious types only. ${ }^{8}$ Thus, we retain a total of 1,722 respondents for our analysis, divided into the three theoretically required types of religion: nonreligious (37 percent), Christian (48 percent), and New Age (15 percent).

Rationalism has been measured by means of seven Likert-type items taken from De Meere (1996:72) that ascertain the extent to which one believes that true and objective scientific knowledge exists, which can be applied in the form of technology in order to control the environment. The seven items, their distributions, and their loadings on the common underlying factor are presented in Table 2. Combination of the seven items yields a scale that reliably (Cronbach's $\alpha=0.79)$ and validly measures rationalism.

As discussed above, individualism refers to the granting of a moral primacy to individual liberty. Research by Middendorp (1991) points out that this moral type of individualism is especially indicated by a rejection of authoritarianism, a rejection of traditional ideas about family life and sexuality, and a democratic inclination. Middendorp (1991:259-62) also considers Inglehart's well-known index for "postmaterialism" a measure for this type of individualism, and to justice, 


\section{TABLE 2}

\section{FACTOR ANALYSIS OF SEVEN ITEMS INDICATING RATIONALISM}

\begin{tabular}{|c|c|c|}
\hline Items & $\begin{array}{l}\% \text { Agree } \\
\text { (Strongly) }\end{array}$ & Factor 1 \\
\hline Thanks to technological developments we can handle future problems. & 65.1 & 0.75 \\
\hline $\begin{array}{l}\text { The further the natural sciences get, the less accidents will take place in technical } \\
\text { installations. }\end{array}$ & 44.6 & 0.73 \\
\hline Science and technology only make our lives easier. & 61.8 & 0.69 \\
\hline $\begin{array}{l}\text { Accidents in technical installations can be banished by means of conscientious } \\
\text { scientific research. }\end{array}$ & 60.1 & 0.66 \\
\hline $\begin{array}{l}\text { Risks tied to new technologies should be seen as temporary problems, which will } \\
\text { be solved later. }\end{array}$ & 46.8 & 0.64 \\
\hline Scientists deserve great social appreciation. & 57.9 & 0.60 \\
\hline Science and technology will eventually do the world more harm than good. & 15.6 & -0.59 \\
\hline Eigenvalue & & 3.1 \\
\hline Variance explained $(\%)$ & & 44 \\
\hline Cronbach's $\alpha$ & & 0.79 \\
\hline
\end{tabular}

$\mathrm{N}=1,496$.

as other research has demonstrated (Flanagan 1979, 1982, 1987; Dekker, Ester, and Van den Broek 1999; Houtman 2001). We therefore measure (moral) individualism in this article as the linear combination of an (inverted) scale for authoritarianism, ${ }^{9}$ a scale for sexual permissiveness,${ }^{10}$ and Inglehart's index for postmaterialism. ${ }^{11}$

Finally, age is measured as the number of years $(M=46.4 ; S D=15.2)$.

\section{Education and Gender as Controls}

Previous research demonstrates that affinity with New Age is not only relatively strong among the young, but among the well educated and women, too (e.g., Becker, De Hart, and Mens 1997). Therefore, we add level of education and gender as controls.

As to level of education, it is important to note that the moral type of individualism emphasized by the thesis of individualization is not only prominent among the young, but among the well educated as well (e.g., Inglehart 1977, 1990, 1997; Houtman 2001). So, the well educated not only display a relatively strong affinity with New Age, but also a high level of individualism. This might be more than a coincidence. Indeed, it is likely that the affinity with New Age among the well educated, like that among the young, can be attributed to their high levels of individualism. We use a division into seven categories for the highest level of education completed: (1) no/adapted primary education (4 percent), (2) primary education (16 percent), (3) lower secondary education (14 percent), (4) intermediate secondary education (20 percent), (5) higher secondary education (12 percent), (6) college (21 percent), and (7) university (12 percent).

As to gender, 44 percent of our respondents are female and 56 percent are male. We know of no research demonstrating gender differences with respect to individualism, but such differences seem to exist with respect to rationalism. As it happens, women display less affinity with natural science and technology and stronger environmental concern, both of which suggest weaker rationalism. Moreover, those low levels of rationalism among women are not limited to the public at large (Blocker and Eckberg 1989, 1997; Hornig 1992), but also apply to life scientists (Barke, Jenkins-Smith, and Slovic 1997) and political elites (Cohen 1997). So, the stronger affinity with New Age among women as compared with men might be attributable to weaker rationalism. 


\section{Statistical Method: LISREL}

The three possible combinations of the three mentioned types of religiosity yield three dependent variables to be used in the subsequent analysis: (1) nonreligiosity versus affinity with the Christian tradition, (2) affinity with New Age versus affinity with the Christian tradition, and (3) affinity with New Age versus nonreligiosity. Normal OLS regression cannot be used to test our hypotheses because these are dichotomous dependent variables. However, the most obvious alternative, logistic regression, precludes the estimation of path models, which demonstrate how age (and education and gender) indirectly, i.e., through individualism and rationalism, affects type of religiosity, because individualism and rationalism are metric variables. What we need, in short, is a statistical method that, unlike OLS regression and logistic regression, allows for the estimation of path models with metric intervening variables and dichotomous dependent variables. The best choice under those circumstances is LISREL, using the (Generally) Weighted Least Squares (WLS) rather than the common Maximum Likelihood method (Jöreskog and Sörbom 1993:4450). As the WLS method allows for the inclusion of ordinal variables, it can also be used for our models with dichotomous dependent variables, which can be considered ordinal dichotomizations of theoretical continua. Apart from the also ordinally scaled level of education, all other variables have a metric level of measurement (with gender represented by a dummy variable).

The input for the LISREL analysis is provided by matrices made with PRELIS, containing polychorical and polyserial correlations and the associated asymptotic covariance matrices. Those correlation matrices confirm that those who have affinity with the Christian tradition are indeed not only older than nonreligious persons $(r=-0.22)$, but also older than those who have affinity with New Age $(r=-0.19)$. Those who have affinity with New Age and those who are nonreligious do not differ with respect to age $(r=0.02)$. So, as compared with Christians, New Agers and nonreligious persons are young, while the two last-mentioned groups do not differ in age. Of course, nothing else was to be expected, as an exodus from the Christian churches has taken place during the last few decades, while in contrast New Age and nonreligiosity have only increased. To test our hypotheses, we estimate path models indicating the extent to which those age effects can be attributed to differences with respect to rationalism and individualism between the old and the young. Therefore, irrespective of their levels of significance, we specify all age effects on individualism, rationalism, and the dependent variables. As to level of education and gender, used as controls, paths have been omitted in cases of nonsignificance.

\section{RESULTS}

The first two hypotheses to be tested relate to the downfall of the Christian churches and the growth of nonreligiosity during the past few decades. Hypothesis 1, derived from the thesis of rationalization, proves untenable (see Figure 2).

Although rationalism marginally increases the likelihood of a person to be nonreligious rather than Christian, the old are not less but more rationalistic than the young, as Beck and Inglehart's work already led us to suspect. It is not true, therefore, that the old are more often Christian than the young because they are less rationalistic. This means that Hypothesis 1, derived from the thesis of rationalization, is rejected.

Hypothesis 2, derived from the thesis of individualization, is confirmed. The young are not only more individualistic than the old, but this individualism also leads them to embrace nonreligiosity rather than the Christian tradition. Although the effects of both age on individualism and individualism on nonreligiosity are substantial, a significant direct effect of age on the distinction between nonreligiosity and Christianity remains. Although survey data do not permit an easy test of this possibility, we might speculate that this results from a weakening ability (itself a likely consequence of the decline of Christian cultural dominance) of tradition, convention, habit, or custom to lead young people to associate themselves with one of the 
FIGURE 2

NONRELIGIOSITY (VERSUS AFFINITY WITH CHRISTIANITY) EXPLAINED $(\mathbf{N}=$ 1,310, CHI-SQUARE $=3.91, \mathrm{df}=4, p=0.42 ; \mathrm{R}^{2}$ NONRELIGIOSITY $=16 \%, \mathrm{R}^{2}$ RATIONALISM $=5 \%, R^{2}$ INDIVIDUALISM $=15 \%$; ALL PATHS SHOWN ARE SIGNIFICANT $(p<0.05)$, UNLESS MARKED n.s.)

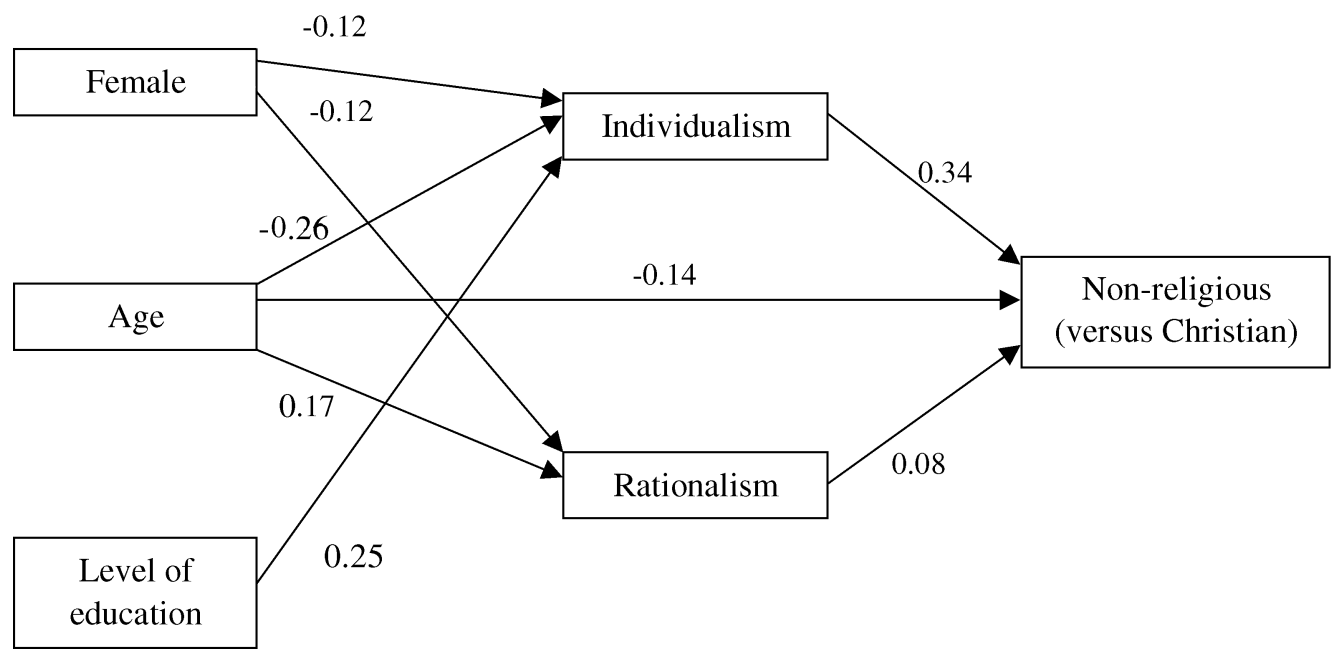

Christian churches (that is, independent of their personal judgment as to the desirability of such an association).

For the testing of Hypothesis 3, also derived from the thesis of individualization, we now compare New Agers to Christians (Figure 3). It is evident that the young are not only more individualistic than the old, but that their individualism also contributes substantially to a preference for New Age rather than Christianity. In contrast with Figure 2, which compares Christians and nonreligious people, no significant direct effect of age on the dependent variable remains in this case. This means that the moral individualism of the young fully accounts for the popularity of New Age rather than the Christian churches among them. Once again, it is difficult to understand why in this case no direct age effect remains. We might speculate that this is because New Age, more than nonreligiosity (Figure 2), constitutes a nontraditional and hardly institutionalized religious option, which for that very reason demands a deliberate value-rational choice. Be this as it may, these findings strikingly confirm Heelas's thesis about the individualism of New Age:

\footnotetext{
those who think in terms of the ideology of the autonomous self, who attach very great value to being themselves, who attach equal value to expressing what they are, who have a "metaphysical dread of being encumbered by something alien", are much more likely to be attracted to the (relatively) detraditionalized New Age than to other forms of religiosity, namely those which speak the language of externally-informed injunctions, directives: moral rules and regulations. (1996:161-62)
}

Finally, women have more affinity with New Age and men more with the Christian tradition. This gender difference can be attributed to neither individualism, nor rationalism, as it shows up with those two variables held constant.

Figure 4 demonstrates that New Agers and nonreligious persons differ hardly or not at all with respect to either age or individualism (although the difference is negligible and hardly significant, New Agers are even somewhat more individualistic than nonreligious people). This is quite an important finding, as it means that the rising level of individualism since the 1960s has reduced support for the Christian tradition considerably, while it combines just as easily with nonreligiosity as with New Age. 
FIGURE 3

AFFINITY WITH NEW AGE (VERSUS AFFINITY WITH CHRISTIANITY) EXPLAINED $\left(\mathrm{N}=957\right.$, CHI-SQUARE $=3.05, \mathrm{df}=5, p=0.69 ; \mathrm{R}^{2}$ AFFINITY WITH

NEW AGE $=19 \%, R^{2}$ RATIONALISM $=7 \%, R^{2}$ INDIVIDUALISM $=14 \% ; A L L$ PATHS SHOWN ARE SIGNIFICANT $(p<0.05)$, UNLESS MARKED n.s.)

\subsection{5}

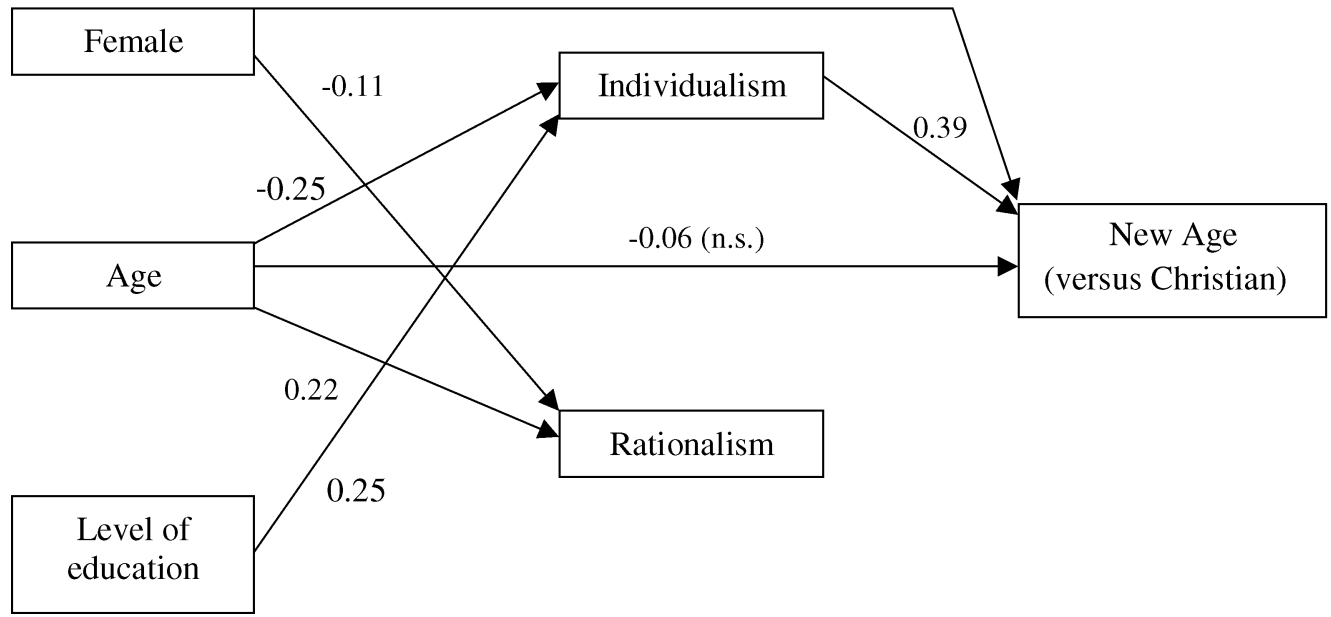

Finally, some remarks about the effects of gender and level of education, two variables that have been added as controls. As to gender, the Christian tradition is equally strongly accepted by men and women (Figure 2), but women have a stronger affinity with New Age than do men (Figure 4). Moreover, this gender difference is substantial. First, of course, this underscores the importance of distinguishing between different types of religion in empirical research. After all,

FIGURE 4

AFFINITY WITH NEW AGE (VERSUS NONRELIGIOSITY) EXPLAINED ( $\mathbf{N}=811$, CHI-SQUARE $=0.52, \mathrm{df}=4, p=0.97 ; \mathrm{R}^{2}$ AFFINITY WITH NEW AGE $=10 \%, \mathrm{R}^{2}$ RATIONALISM $=8 \%, R^{2}$ INDIVIDUALISM $=15 \%$; ALL PATHS SHOWN ARE SIGNIFICANT $(p<0.05)$, UNLESS MARKED n.s. $)$

\subsection{1}

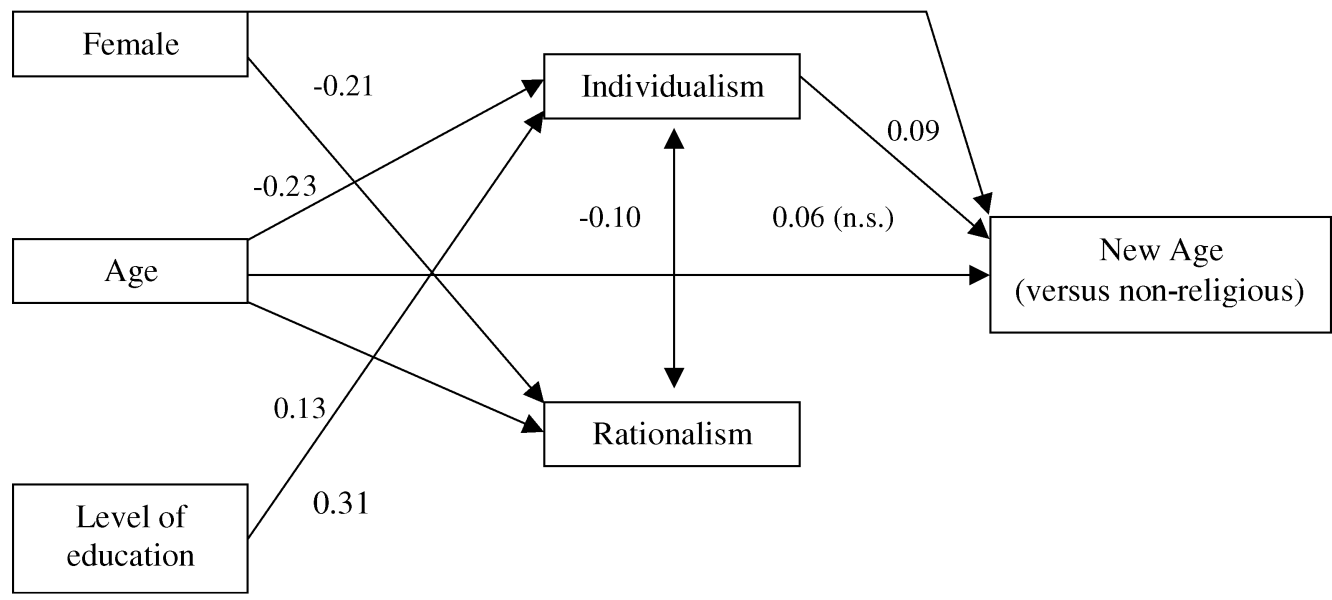


such a finding by definition cannot be explained by means of a theory relying on a distinction between "religion" and "nonreligion" rather than between different types of religion. Second, our hunch that female affinity with New Age might be attributable to weaker female rationalism was clearly mistaken. Although, as expected, all three path models confirm that women are somewhat less rationalistic than men, this rationalism fails to affect affinity with New Age negatively. As an aside, it is quite interesting to note that none of the papers referred to above, which demonstrate low levels of female affinity with natural science and technology and high levels of female environmental concern, succeeds in developing, testing, and confirming a satisfactory explanation for those gender differences. Although the causes of female affinity with New Age are only tangential to our present concerns, it is extremely important, of course, to gain an understanding of this substantial gender difference. For the moment, however, we can only conclude that it cannot be attributed to low levels of rationalism among women. This remains an intriguing and theoretically important puzzle to be solved by future research.

Unlike the gender effects, those of education can be interpreted in accordance with our hunch as formulated above. As expected, high levels of moral individualism among the highly educated are responsible for their affinity with New Age.

\section{Conclusion and Debate}

Why do the Dutch churches become empty, while New Age grows? Our main conclusion is that both the decline of Christianity and the growth of New Age during the last few decades can be understood against the background of a process of individualization. The prevalence of affinity with New Age and nonreligiosity among the young and of Christianity among the old can to a large extent be attributed to a stronger moral individualism among the former. So, although the process of individualization has seriously undermined the moral basis of the Christian tradition, it cannot be said to have undermined all sorts of religion. On the one hand, those findings confirm the thesis of individualization, as found in the work of Luckmann (1967) and Heelas (1996): an increase of moral individualism undermines the Christian churches and stimulates the growth of posttraditional types of religion, among which New Age figures prominently. On the other hand, however, our findings indicate that their version of the thesis of individualization wrongly neglects a second consequence of an increase of moral individualism. As it happens, this process not only drives a growth of New Age (religious change), but a growth of nonreligiosity (secularization) as well. Indeed, as we have seen, (post)modern individualism combines with New Age just as easily as with nonreligiosity. In short, a process of individualization has caused the decline of the Christian churches since the 1960s and the rise of New Age and nonreligiosity during the same period.

Our second conclusion is that the thesis of rationalization is untenable. This conclusion is supported by two empirical arguments. First, nonreligious persons are hardly more rationalistic than Christians, whereas nonreligious persons and New Agers do not differ at all in this respect. As such, the assumption underlying the thesis of rationalization - that strained relationships exist between rationalism on the one hand and any type of religion on the other-is untenable (see also Stark and Finke 2000). Second, and consistent with contemporary literature on "reflexive modernization" (Beck 1992) and "postmodernization" (Crook, Pakulski, and Waters 1992; Inglehart 1997), an increase of rationalism seems not even to have taken place during the last few decades: strongest rationalism is not found among the young, but among the elderly.

Finally, two important questions about the limitations of our study deserve attention. First, we want to make some remarks on the generalizability of our findings. Do they apply to the Netherlands only or can they be generalized to Western society generally? Second, to prevent a misunderstanding of our findings, it is important to make some additional remarks on the thesis of rationalization and the concept of "rationalism" as it figures within it. What should be made of our rejection of the widely held theory that secularization is driven by rationalization? 
As to the generalizability of our findings, it needs to be emphasized that there are not many countries in which the Christian tradition has eroded so rapidly and dramatically as in the Netherlands. The United States in particular has experienced less secularization than most other Western societies. Nevertheless, in their pioneering work, The Future of Religion (1985), Stark and Bainbridge demonstrate that posttraditional types of religion flower in exactly those parts of the United States where the Christian churches have declined most. So, in the United States, too, a decline of the Christian churches and a growth of posttraditional religions like New Age tend to go hand in hand. Although it is unclear whether those American social contexts, characterized by relatively low levels of Christian church membership and relatively high levels of posttraditional religions like New Age, are at the same time social contexts with high levels of moral individualism, this is quite likely. As it happens, the process of individualization, conceived of as a growth of moral individualism, is certainly not a typical Dutch phenomenon. Inglehart (1997) even claims quite convincingly that we are dealing with a global development here. So, although the decline of the Christian churches and the growth of New Age may have been more dramatic in the Netherlands than elsewhere, we consider it likely that increasing levels of moral individualism have had similar consequences in other countries. As such, the thesis of individualization poses an alternative interpretation for the empirical patterns established by Stark and Bainbridge. For future research, therefore, it is important to develop and systematically test competitive hypotheses from the Stark and Bainbridge supply-side model and the thesis of individualization as it has been confirmed for the Netherlands in this article.

As to our rejection of the widely held thesis of rationalization, it is necessary to elaborate on our conceptualization and measurement of rationalism. The thesis of rationalization conceives of rationalism as the conviction that true and objective scientific knowledge exists, which can be applied in the form of technology to control the environment. Obviously, this conviction cannot be equated with scientific rationality, as the latter also (and arguably more strongly) refers to doubt, skepticism, and the rejection of all sorts of taken-for-granted beliefs about reality. Indeed, uncompromising compliance with the "truth imperative" is at least equally likely to yield relativism and nihilism rather than faith in the existence of definitive and unassailable scientific knowledge (Goudsblom 1980; compare Osborne 1998). It is also likely, then, that scientific rationality does not undermine religion through an awareness of growing piles of unquestionable knowledge, as the thesis of rationalization assumes, but through an increase of doubt, skepticism, relativism, and nihilism. As we have argued above, the latter possibility is implied in Max Weber's classical work on the disenchantment of the world and is theorized in contemporary work on reflexive modernization and postmodernization. In short, we consider it likely that a spread of scientific rationality undermines religion, but such a process does not seem to come about through the mechanism assumed by the thesis of rationalization.

Our findings indicate that both principal pillars of Western culture, rationalism and Christianity, have been showing increasing wear and tear during the past few decades. In the form of New Age, gnosticism, which has subsisted for centuries as a relatively marginal cultural movement, has gained considerable popularity during this same period. Closely related to the process of individualization, the gnostic idea that "truth" cannot be reached through "faith" or "reason," but requires personal experience ("gnosis"), seems to have become more widespread (Hanegraaff 1996; compare also Lasch 1992 and Gellner 1992). It is important to underscore that youthful cultural and political discontent during the 1960s, commonly regarded as an acceleration of the process of individualization (e.g., Inglehart 1977) exhibited gnostic tendencies as well (Zijderveld 1970; see also Berger, Berger, and Kellner 1973; Bell 1976). As such, the growth of New Age is not only an important object of study for sociologists of religion, but is of considerable relevance for sociologists of culture and political sociologists as well.

Its very relevance to the understanding of modern culture, however, inevitably implies that New Age is quite controversial and capable of arousing deeply felt likes and dislikes. It is telling that sociologists' most common rejections of New Age as a significant new religious phenomenon 
seem affected by two discourses of modernity, which underlie two long-standing theoretical traditions within the sociology of religion (e.g., Tschannen 1991). In an ideal-typical sense, first, there are those who worry about "moral decline" and "loss of norms and values" as dismal consequences of the downfall of the Christian churches. Those who worry thus are unlikely to consider New Age a "real" religion because in failing to provide the binding moral values needed to contain (post)modern individualism, it is not a serious alternative to the Christian tradition (e.g., Wilson 1976, 1982; Dobbelaere 1999). Worse, it even embraces this (post)modern individualism. Second, there are those who welcome secularization as a decline in "superstition," "ignorance," and "irrationality." These people are equally unlikely to consider New Age an important new religious phenomenon. After all, because they hold that religion disappears as science and technology develop, New Age must be either a final religious convulsion or something that has nothing to do with religion at all. The very relevance of New Age for an understanding of modern culture, in short, gives rise to great difficulties in disentangling empirical facts, theoretical interpretations, and moral discourses.

\section{ACKnOWledgments}

A previous version of this article was presented at an international conference, the Spiritual Supermarket: Religious Pluralism and Globalisation in the 21st Century, London School of Economics, April 19-22, 2001. The authors wish to acknowledge financial support by the research group Modernization and Social Inequality, the Faculty of Social Sciences of Erasmus University, and the Vereniging Trustfonds Rotterdam, without which the research presented in this article could not have been conducted. They thank Stef Aupers and two anonymous reviewers for their useful comments on previous versions of this paper, Jan Koster for his methodological advice, and Manu Busschots, Anouk de Rijk, Robert Boogaard, and especially Inge van der Tak for their invaluable contributions as research assistants during different stages of the project.

\section{Notes}

1. To test this hypothesis (as well as two further hypotheses), we need to make an additional methodological assumption, which will be discussed later.

2. Inglehart himself does not speak of increasing "moral individualism," but of increasing "postmaterialism."

3. For example, "moral progressiveness," "cultural progressiveness," "self-directedness," "social liberalism," and "libertarianism," understood as the opposite poles of, respectively, "moral conservatism," "cultural conservatism," "conformism," "social conservatism," and "traditionalism," or "authoritarianism."

4. Of course, this distinction between two variants of the thesis of individualization is not necessary if one is, like Luckmann (1967), prepared to stretch the notion of religion to include almost any type of cultural expression. Those counted as nonreligious in the current article, for instance, could then also be regarded religious-be it in highly diverse and contestable ways-thus excluding the possibility of a decline of religion by definition (see Hamilton 1995:163-64).

5. The underlying reasoning is, of course, that the fact that the young are more highly educated than the old cannot be a life-cycle effect by definition, as it is impossible for an already received education to disappear again.

6. The strong positive relationship between individualism and level of education has been common knowledge in the social sciences for at least the last half century. However, some of the most conventional sociological interpretations of this relationship, which to a certain extent contradict one another, appear to be untenable when thoroughly tested (Houtman 2001). On the other hand, we know of no research that demonstrates higher levels of rationalism among the highly educated than among the poorly educated.

7. With the percentages "rather/very intensively involved" or "(strongly) agree" between brackets, the factor loadings are 0.75 for reincarnation (19.6), 0.74 for astrology (22.0), 0.60 for New Age (10.5), 0.55 for Yoga (19.2), 0.54 for oriental religions (24.6), 0.62 for "One's character is strongly determined by the stars and planets" (13.1), 0.53 for "One can predict one's future to a large extent by reading the lines in one's hand" (7.0), 0.59 for "After death, one's soul passes to another human being or animal" (9.7), 0.46 for "One should search in different religions yourself to make one's own religion" (26.7), and 0.41 for "The one and only true faith does not exist, but there are truths one can find in all religions of the world" (72.5).

8. The limited size of this mixed category is probably because the Christian tradition and New Age do not endure each other very well (compare Becker, De Hart, and Mens 1997:146-52). With respect to age and individualism, this mixed type takes up the expected middle position between Christians and New Agers. On average, those involved are older than New Agers and younger than Christians (47.2, 43.9, and 49.1 years, respectively; $\eta=0.16 ; p<0.01$ ) and less 
individualistic than New Agers, but more than Christians (49.2, 58.2, and 45.7, respectively; $\eta=0.30 ; p<0.01$ ). There are no differences with respect to rationalism.

9. The eight items of the shortened F-scale (Cronbach's $\alpha=0.80$ ) with, respectively, the percentage "agree (strongly)" and the loading on the first factor in brackets, are: (1) "Our social problems would largely be solved if we could somehow remove criminal and antisocial people from society" (31.7; 0.71$)$; (2) "What we need is less laws and institutions and more brave and dedicated leaders whom the people can trust" (23.7; 0.68); (3) "If people would talk less and work harder, everything would be better" $(29.7 ; 0.67)$; (4) "There are two kinds of people: the strong and the weak" (22.4; 0.65); (5) "One can hardly expect a person with bad manners, habits and upbringing to mix well with decent people" (38.5; 0.65); (6) "Young people sometimes get rebellious ideas, but when they grow older, they should get over them and adapt to reality" (50.2; 0.60); (7) "Sexual crimes, like rape and assault of children deserve more than just prison sentences; such criminals should receive corporal punishment in public" (38.2; 0.59); and (8) "Most people are disappointing once one gets to know them better" $(15.2 ; 0.52)$.

10. The six items indicating sexual permissiveness (Cronbach's $\alpha=0.77$ ) with, respectively, the percentage "agree (strongly)" and the factor loading in brackets, are: (1) "Too much sex is shown on television" $(45.8 ;-0.76) ;(2)$ "One should only have sexual contact with one's regular partner" $(64.6 ;-0.73)$; (3) "People are free to have sexual fantasies about people around them" $(63.9 ; 0.62)$; $(4)$ "Sex is talked and written about much too freely and openly" $(22.1 ;-0.76) ;(5)$ "Having sex should be done with two persons" $(69.3 ;-0.71)$; and (6) "People are free to passionately kiss each other in public" $(55.2 ; 0.48)$. Scale scores are given to all respondents who have answered "don't know" to a maximum of two items.

11. In the case of postmaterialism, we use factor scores, which are adopted from a factor analysis on the prioritization of the four political goals used for its measurement. Factor analysis of the three mentioned indicators of individualism then produces one single factor, which explains 52 percent of the variance. Factor loadings are 0.80 for the (inverted) scale for authoritarianism, 0.71 for postmaterialism, and 0.64 for sexual permissiveness.

\section{References}

Aupers, S. 2000. Werken aan lichaam, emoties en energie in New Age-centra: Een 'hertovering'? [Working at body, emotions, and energy in new age centers: A "re-enchantment"?] Sociologische Gids 47(5):350-65.

Bader, C. and A. DeMaris. 1996. A test of the Stark-Bainbridge theory of affiliation with religious cults and sects. Journal for the Scientific Study of Religion 35(3):285-303.

Barke, R. P., H. Jenkins-Smith, and P. Slovic. 1997. Risk perceptions of men and women scientists. Social Science Quarterly 78(1):167-76.

Beck, U. 1992. Risk society: Towards a new modernity. London: Sage.

Beck, U., A. Giddens, and S. Lash. 1994. Reflexive modernization: Politics, tradition and aesthetics in the modern social order. Stanford, CA: Stanford University Press.

Becker, J. W., J. De Hart, and J. Mens. 1997. Secularisatie en alternatieve zingeving in Nederland [Secularization and alternative religion in the Netherlands]. Rijswijk: SCP.

Becker, J. W. and J. S. J. De Wit. 2000. Secularisatie in de jaren negentig [Secularization in the nineties]. The Hague: SCP.

Becker, J. W. and R. Vink. 1994. Secularisatie in Nederland, 1966-1991 [Secularization in the Netherlands, 1966-1991]. Rijswijk: SCP.

Bell, D. 1976. The cultural contradictions of capitalism. New York: Basic Books.

Berger, P., B. Berger, and H. Kellner. 1973. The homeless mind: Modernization and consciousness. New York: Vintage Books.

Bernts, T. and H. Van der Hoeven. 1998. Tussen Rooms en Redfield: De belangstelling voor traditionele en alternatieve religie [Between Roman and Redfield: Interest in traditional and alternative religion]. Sociale Wetenschappen 41(2):5769.

Blocker, T. J. and D. L. Eckberg. 1989. Environmental issues as women's issues: General concerns and local hazards. Social Science Quarterly 70(3):586-93.

. 1997. Gender and environmentalism: Results from the 1993 General Social Survey. Social Science Quarterly 78(4):841-58.

Bruce, S. 1995. The truth about religion in Britain. Journal for the Scientific Study of Religion 34(4):417-30.

Cohen, N. 1997. The politics of environmental risk: Perceptions of risk assessment in the state legislatures. Policy Studies Journal 25(3):470-84.

Comte, A. 1974 [1851-1854]. The essential Comte (selected from Cours de la Philosophie Positive by A. Comte), edited and introduced by S. Andreski. London: Croom Helm.

Crook, S., J. Pakulski, and M. Waters. 1992. Postmodernization: Change in advanced society. London: Sage.

De Hart, J. 1993. Jongeren en "new age": Recente cijfers betreffende de betrokkenheid van jong volwassenen bij alternatieve levensbeschouwelijke stromingen [Youngsters and "new age": Some recent figures concerning the involvement of young adults in alternative religious movements]. Sociale Wetenschappen 36(1):1-23. 
Dekker, P., P. Ester, and A. Van den Broek. 1999. Fixing left and right: Value orientations according to Middendorp and Inglehart. In Ideology in the Low Countries: Trends, models and lacunae, edited by H. De Witte and P. Scheepers, pp. 151-76. Assen: Van Gorcum.

De Meere, F. 1996. U kunt gerust gaan slapen .... Denkbeelden over technologie, risico's en samenleving [You can safely go to sleep: Beliefs about technology, risk, and society]. Delft: Eburon.

Dobbelaere, K. 1993. Individuele godsdienstigheid in een geseculariseerde samenleving [Individual religiosity in a secularized society]. Tijdschrift voor Sociologie 14(1):5-29.

- 1999. Towards an integrated perspective of the processes related to the descriptive concept of secularization. Sociology of Religion 60(3):229-47.

Flanagan, S. C. 1979. Value change and partisan change in Japan: The silent revolution revisited. Comparative Politics 11(3):253-78.

1982. Changing values in advanced industrial societies: Inglehart's silent revolution from the perspective of Japanese findings. Comparative Political Studies 14(4):403-44.

1987. Value change in industrial societies: Reply to Inglehart. American Political Science Review 81(4):1303-19.

Gadourek, I. 1998. On the variability of social life: A few empirical studies. Groningen: Groningen University.

Gellner, E. 1992. Postmodernism, reason and religion. London and New York: Routledge.

Goudsblom, J. 1980. Nihilism and culture. Oxford: Blackwell.

Gross, P. R. and N. Levitt. 1994. Higher superstition: The academic left and its quarrels with science. Baltimore, MD: Johns Hopkins University Press.

Gussenhoven, J. and V. Van den Maagdenberg. 1998. Ik is God: Een onderzoek naar individualisme en New Age [I is God: A study into individualism and New Age] (unpublished paper).

Hamilton, M. B. 1995. The sociology of religion: Theoretical and comparative perspectives. London: Routledge.

Hanegraaff, W. J. 1996. New Age religion and Western culture: Esotericism in the mirror of secular thought. Leiden: Brill.

Heelas, P. 1996. The New Age movement: The celebration of the self and the sacralization of modernity. Oxford: Blackwell.

Heelas, P., S. Lash, and P. Morris (eds.). 1995. Detraditionalization: Critical reflections on authority and identity. Oxford: Blackwell.

Hornig, S. 1992. Gender differences in responses to news about science and technology. Science, Technology, and Human Values 17(4):532-42.

Houtman, D. 2001. Class, culture, and conservatism: Reassessing education as a variable in political sociology. In The breakdown of class politics: A debate on post-industrial stratification, edited by T. N. Clark and S. M. Lipset, pp. 161-96. Baltimore, MD: Johns Hopkins University Press.

Iannaccone, L., R. Stark, and R. Finke. 1998. Rationality and the religious mind. Economic Inquiry 36(3):373-89.

Inglehart, R. 1977. The silent revolution: Changing values and political styles among Western publics. Princeton, NJ: Princeton University Press.

. 1990. Culture shift in advanced industrial society. Princeton, NJ: Princeton University Press.

. 1997. Modernization and postmodernization: Cultural, economic, and political change in 43 countries. Princeton, NJ: Princeton University Press.

Janssen, J. 1998. The Netherlands as an experimental garden of religiosity. Social Compass 45(1):109-22.

Jöreskog, K. and D. Sörbom. 1993. LISREL 8: Structural equation modelling with the SIMPLIS command language. Chicago, IL: Scientific Software International.

Lambert, Y. 1999. Religion in modernity as a new axial age: Secularization or new religious forms? Sociology of Religion 60(3):303-33.

Lasch, C. 1992. Gnosticism, ancient and modern: The religion of the future? Salmagundi 96:27-42.

Lechner, F. J. 1991. The case against secularization: A rebuttal. Social Forces 69(4):1103-19.

Luckmann, T. 1967. The invisible religion. London: MacMillan.

- 1996. The privatization of religion and morality. In De-traditionalization: Critical reflections on authority and identity at a time of uncertainty, edited by P. Heelas, S. Lash, and P. Morris, pp. 72-86. Oxford: Blackwell.

Meloen, J. and C. Middendorp. 1991. Authoritarianism in the Netherlands: The empirical distribution in the population and its relation to theories of authoritarianism. Politics and the Individual 1(2):49-72.

Middendorp, C. P. 1991. Ideology in Dutch politics: The Democratic system reconsidered (1970-1985). Assen: Van Gorcum.

Miller, A. S. 1995. A rational choice model of religious behavior in Japan. Journal for the Scientific Study of Religion 34(2):234-44.

Moerland, M. and A. Van Otterloo. 1996. New Age: Tegencultuur, paracultuur of kerncultuur? [New Age: Counter culture, paraculture, or core culture?]. Amsterdams Sociologisch Tijdschrift 23(4):682-710.

Nock, D. A. 1989. Differential ecological receptivity of conversionist and revolutionist sects: A reconsideration of Stark and Bainbridge. Sociological Analysis 50(3):229-46.

Olson, D. V. A. and J. W. Carroll. 1992. Religiously based politics: Religious elites and the public. Social Forces 70(3):765-86.

Osborne, T. 1998. Aspects of enlightenment: Social theory and the ethics of truth. London: UCL Press. 
Robertson, R. 1992. The economization of religion? Reflections on the promise and limitations of the economic approach. Social Compass 39(1):147-57.

Roof, W. C. 2000. Spiritual seeking in the United States: Report on a panel study. Archives de Sciences Sociales des Religions 45(109):49-66.

Roof, W. C., J. W. Carroll, and D. A. Roozen. 1995. Conclusion: The post-war generation-Carriers of a new spirituality. In The post-war generation and establishment religion: Cross-cultural perspectives, edited by W. C. Roof, J. W. Carroll, and D. A. Roozen, pp. 243-55. Boulder, CO and Oxford: Westview Press.

Sappington, A. A. 1991. The religion/science conflict. Journal for the Scientific Study of Religion 30(1):114-20.

Stark, R. 1999. Secularization, R.I.P. Sociology of Religion 60(3):249-73.

Stark, R. and W. S. Bainbridge. 1985. The future of religion: Secularization, revival, and cult formation. Berkeley, CA: University of California Press.

Stark, R. and R. Finke. 2000. Acts of faith: Explaining the human side of religion. Berkeley, CA: University of California Press.

Te Grotenhuis, M. 1999. Ontkerkelijking: Oorzaken en gevolgen [Dechurching: Causes and consequences]. Nijmegen: Katholieke Universiteit Nijmegen.

Tschannen, O. 1991. The secularization paradigm: A systematization. Journal for the Scientific Study of Religion 30(4):395-415.

Van Otterloo, A. H. 1999. Self spirituality and the body: New Age centers in the Netherlands since the 1960's. Social Compass 46(2):191-202.

Vollebergh, W., J. Iedema, and Q. Raaijmakers. 1999. The intergenerational transmission of cultural and economic conservatism. In Ideology in the Low Countries: Trends, models and lacunae, edited by H. De Witte and P. Scheepers, pp. 51-68. Assen: Van Gorcum.

Voyé, L. 1999. Secularization in a context of advanced modernity. Sociology of Religion 60(3):275-88.

Wallis, R. 1986. Figuring out cult receptivity. Journal for the Scientific Study of Religion 25(4):494-503.

Wallis, R. and S. Bruce. 1984. The Stark-Bainbridge theory of religion: A critical analysis and counter proposals. Sociological Analysis 45(1):11-28.

White, A. D. 1960. A history of the warfare of science with theology in Christendom, 2 vols. New York: Dover Publications. Wilson, B. 1976. Contemporary transformations of religion. Oxford: Oxford University Press. 1982. Religion in sociological perspective. Oxford: Oxford University Press.

Woodrum, E. 1988a. Determinants of moral attitudes. Journal for the Scientific Study of Religion 27(4):553-73. . 1988b. Moral conservatism and the 1984 presidential election. Journal for the Scientific Study of Religion 27(2):192-210

Zijderveld, A. C. 1970. The abstract society: A cultural analysis of our time. Garden City, NY: Doubleday. 